Nevşehir Bilim ve Teknoloji Dergisi (2019), 8(IMSMATEC Özel Sayı) 98-104

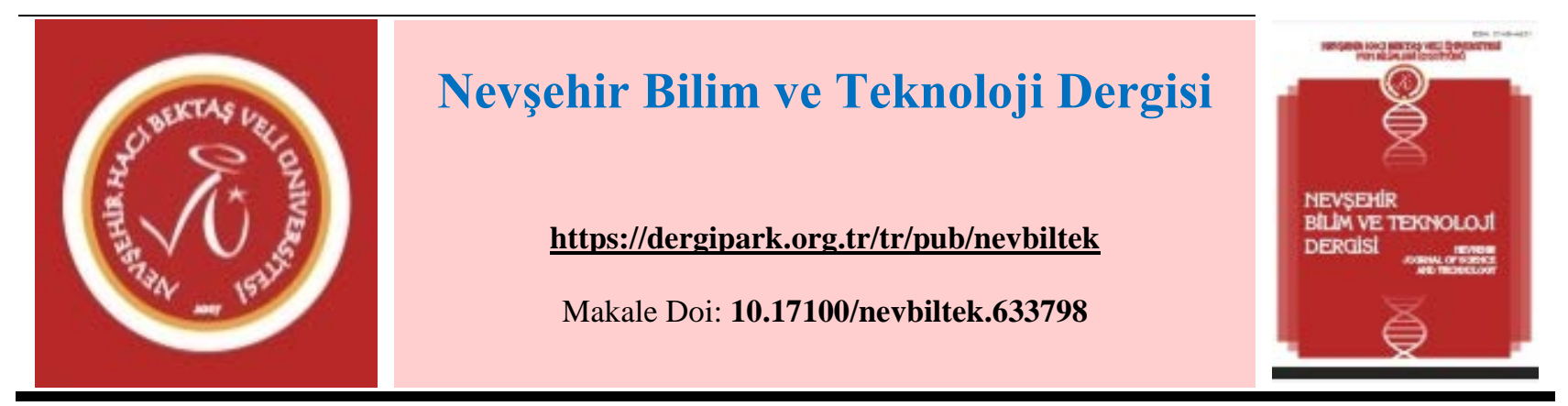

\title{
Toz Metalürjisi Yöntemiyle Üretilen 17-4 PH Paslanmaz Çeliklerde Mo Miktarının Korozyon Davranışlarına Etkisi
}

\author{
Dursun ÖZYÜREK ${ }^{1}$, İjlal ŞIMŞSK ${ }^{2}$, Öznur DİNCEL ${ }^{3}$, Doğan ŞIMSSEK ${ }^{4}$ \\ ${ }^{1}$ Karabük Üniversitesi, Teknoloji Fakültesi, Imalat Mühendisliği Bölümü, Karabük \\ ORCID ID: 0000-0002-8326-9982 \\ ${ }^{2}$ Karabük Üniversitesi, TOBB Teknik Bilimler Meslek Yüksekokulu, Makine ve Metal Teknolojileri Bölümü, Karabük \\ ORCID ID: 0000-0001-6542-8567 \\ ${ }^{3}$ Karabük Üniversitesi, Teknoloji Fakültesi, Imalat Mühendisliği Bölümü, Karabük \\ ORCID ID: 0000-0003-3043-7281 \\ ${ }^{4}$ Milli Savunma Üniversitesi, Kara Astsubay Meslek Yüksekokulu, Otomotiv Teknolojileri Bölümü, Karabük \\ ORCID ID: 0000-0001-8339-9704 \\ $\mathrm{Bu}$ çalışmada, toz metalürjisi yöntemi ile farklı oranlarda molibden ilave edilerek üretilen 17-4 PH paslanmaz çelik alaşımların mikro yapı ve \\ korozyon davranışları incelenmiştir. Hazırlanan alaşım tozlar soğuk preslenerek (800 MPa) ham kompaktlar üretilmiştir. Üretilen ham kompaktlar 10- \\ 6 milibar vakumda $1300{ }^{\circ} \mathrm{C}$ 'de 1 saat sinterlenerek, firın ortamında oda sıcaklığına soğutulmuştur. Üretilen numuneler taramalı elektron mikroskobu \\ (SEM+EDS), X-ışını kırınımı (XRD), yoğunluk ve sertlik ölçümleri ile incelenmiştir. Yapılan çalışmalar sonucunda, 17-4 PH paslanmaz çeliğin \\ yoğunluklarının artan Mo miktarı ile birlikte arttı̆̆ı, sertliklerinin ise azaldığı belirlenmiştir.
}

Öz

Anahtar Kelimeler: 17-4 PH alaşımları, molibden, toz metalürisi, mikro yapı, korozyon.

\section{Effect of Mo Amount on Corrosion Behavior of 17-4 PH Stainless Steels Produced by Powder Metallurgy Method}

Abstract

In this study, corrosion behaviour of 17-4 PH stainless steel alloys was investigated which were produced by powder metallurgy method by adding molybdenum at different amounts. Prepared alloy powders were cold pressing (800 MPa) to produce green compacts. Produced green compacts were sintered in $10^{-6}$ mbar vacuum at $1300{ }^{\circ} \mathrm{C}$ for $1 \mathrm{~h}$ and cooled down to room temperature in the furnace. Sintered components were examined by scanning electron microscopy (SEM + EDS), X-ray diffraction (XRD), and density and hardness measurements. As a result of the studies, it was determined that density of 17-4 PH stainless steels increased with increasing Mo amount and the hardness decreased with the addition of amount of Mo.

Keywords: 17-4 PH alloys, molybdenum, powder metallurgy, microstructure, corrosion. 


\section{Nevşehir Bilim ve Teknoloji Dergisi (2019), 8(IMSMATEC Özel Say1) 98-104}

\section{Giris}

Alaşım elementi olarak (ağırlıkça) \% $17 \mathrm{Cr}, \% 4 \mathrm{Ni}$, \% $3 \mathrm{Cu}$ içeren 17-4 PH paslanmaz çelikler, iyi korozyon direnci ve düşük maliyeti nedeniyle yaygın olarak kullanılmaktadır. Bu alaşımların diğer bir özellikleri ise çökelme ile sertleşebilirlikleridir. Sertleşebilirlik, paslanmaz çeliklerin korozyon direncini korurken, yüksek mukavemet ve sertlik değerleri elde etmek için geliştirilen malzemeler arasındadır [1 ve 2]. Bu alaşımlar, yüksek mukavemet, kırılma tokluğu, iyi kaynaklanabilir ve işlenebilirlik özellikleri nedeniyle kimya endüstrisi, enerji santrallerinde, hafif su reaktörleri, basınçlı su reaktörlerinde pompaların ve vanaların parçaları olarak kullanılmaktadır [3 ve 4]. 17-4 PH alaşımları yaşlandırma işlemleri ile mekanik özellikleri geliştirilebilirken korozyon özellikleri ise olumsuz olarak etkilenmektedir. $\mathrm{Bu}$ durum paslanmaz çeliklerin önemli sorunlarından biridir. Yaşlandırma ile işleminde, krom karbürlerin oluşumu difüzyonla meydana gelir ve genel olarak tane sınırlarında yoğunlaşır. Bu durum daha sonra dar bir bölgede krom tükenmesiyle sonuçlanır. Bir elektrolit içerisinde ise bu bölgeler anodik hale gelir. Genel olarak karbürlerin çökelmesinin sonucu korozyon direncini önemli ölçüde etkilemektedir [5]. Bunun yanı sıra, 17-4 PH paslanmaz çeliklerde alaşım elementlerinin ilavesi ile mekanik özelliklerin yanı sıra korozyon özellikleri de önemli ölçüde etkilemektedir. Paslanmaz çeliklere ilave edilen Mo (Molibden) ilavesinin çukurcuk korozyon direncini artırmaktadır [6]. Truman vd. [7] yaptıkları bir çalışmada paslanmaz çeliklerin içerisinde Mo muhtevasının artması ile korozyon yüzeyinde pasif bölgelerin genişlediğini, bu nedenle alaşıma ilave edilen Mo ile ilave edilerek korozyon direncinin artacağı belirtilmiştir. Bunun yanı sıra, Karaminezhaad vd. [8], yaptıkları çalışmada 17-4 PH paslanmaz çelik alaşımına ilave edilen molibdenin korozyon direnci üzerine olumlu etkisi olduğunu, bunun nedeninin ise molibden içeriğinin artması ile alaşımın mukavemetinin azaltarak $\delta$-ferrit fazının gelişmesinden kaynaklandığını belirtmişlerdir.

Yapılan bu çalışmada, toz metalürjisi yöntemi ile 17-4 PH alaşımına farklı miktarlarda Mo ilave edilerek paslanmaz çelik alaşımı üretilmiştir. Üretilen 17-4 PH paslanmaz çeliklerin içeriğinde farklı miktarlarda ilave edilen molibdenin mikro yapı, sertlik ve korozyon davranışları üzerine etkisi belirlenmesi hedeflenmiştir.

\section{Materyal ve Metot}

Deneysel çalışmalarda kullanılan tozlar Alfa Aesar (Germany) firmasından temin edilmiştir. 17-4 PH paslanmaz çeliklerin üretiminde $\mathrm{Cu}(\%$ 99) $44 \mu \mathrm{m}, \mathrm{Fe}(\% 99,9) 10 \mu \mathrm{m}, \mathrm{Cr}(\% 99) 44 \mu \mathrm{m}, \mathrm{Mn}(\%$ 99,8) $44 \mu \mathrm{m}, \mathrm{Ni}(\%$

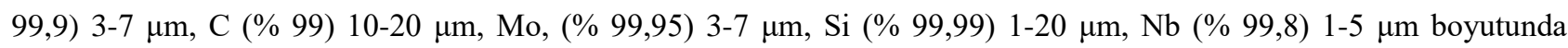
elementel tozlar kullanılmıştır. Tablo 1'de dört farklı oranda (\% ağırlık) Mo ilave edilerek üretilen 17-4 PH paslanmaz çelik alaşımların kimyasal bileşimleri verilmiştir.

Tablo 1. Deneysel çalışmalarda kullanılan 17-4 PH paslanmaz çeliklerin kimyasal bileşimleri

\begin{tabular}{lccccccccccc}
\hline & $\mathbf{C r}$ & $\mathbf{C u}$ & $\mathbf{N i}$ & $\mathbf{M n}$ & $\mathbf{S i}$ & $\mathbf{M o}$ & $\mathbf{N b}$ & $\mathbf{C}$ & $\mathbf{F e}$ \\
\hline $\mathbf{0 , 5}$ Mo & 17 & 4 & 4 & 1 & 1 & $\mathbf{0 , 5}$ & 0,3 & 0,07 & Kalan \\
$\mathbf{1}$ Mo & 17 & 4 & 4 & 1 & 1 & $\mathbf{1}$ & 0,3 & 0,07 & Kalan \\
$\mathbf{2}$ Mo & 17 & 4 & 4 & 1 & 1 & $\mathbf{2}$ & 0,3 & 0,07 & Kalan \\
$\mathbf{4}$ Mo & 17 & 4 & 4 & 1 & 1 & $\mathbf{4}$ & 0,3 & 0,07 & Kalan \\
\hline
\end{tabular}

Temin edilen elementel tozlar, 1/10000 hassasiyetindeki terazide tartılarak, Turbula Shaker Mixer (T2F Glenn Mills) karıştırıcıda $120 \mathrm{rpm}$ ile 120 dakika karıştırılmıştır. Hazırlanan alaşım tozlar soğuk preslenerek (800 MPa) Ø10x7 mm boyutunda ham kompaktlar üretilmiştir. Ön şekillendirilmiş 17-4 PH paslanmaz çelik ham kompaktlar 1300 ${ }^{\circ} \mathrm{C}$ 'de, 60 dakika sinterlenerek (10-6 milibar vakumda ve $4{ }^{\circ} \mathrm{C} / \mathrm{dak}$ 1sıtma hızında), firında oda sıcaklığına soğutulmuştur. Yoğunluk ölçümleri Arşimet prensibine göre yapılmıştır. Sertlik ölçümleri Shimadzu marka mikro 
Nevşehir Bilim ve Teknoloji Dergisi (2019), 8(IMSMATEC Özel Sayı) 98-104

sertlik ölçüm cihazında (HV0,5) yapılmıştır. Sertliklerin belirlenmesinde beş ölçümün ortalaması alınmıştır. Sinterlenen ve daha sonra yaşlandırılan numunelerin yüzeyleri standart metalografik işlemler ile hazırlandıktan sonra, tüm numuneler \% 25 oksalik asit, \% 75 saf su içeren çözeltide elektrolitik dağlama (12 V) ile dağlanmıştır. Dağlanan numuneler (SEM+EDS) (Carl Zeiss Ultra Plus Gemini Fesem) marka tarama elektron mikroskobu ve X-1şını kırınımı (XRD) ile (Rigaku Ultra IV) incelenmiştir. Korozyon testleri Iviumstat bilgisayar kontrollü potansiyostat/galvanostat test cihazında yapılmıştır. Korozyon testlerinde potansiyodinamik polarizasyon tekniği kullanılmıştır. Numuneler açık devre potansiyeline (OCP) ulaşılana kadar 30 dakika bekletilmiştir. Polarizasyon ölçümleri üç elektrot tekniğine göre Ag/AgCl referans elektrot, bir platin levha ve karşıt elektrot kullanılarak bir korozyon hücresi içerisinde yapılmıştır. Elektrolit ortam olarak 0,1 $\mathrm{M} \mathrm{H}_{2} \mathrm{SO}_{4}$ çözeltisi kullanılmıştır. Testler $\pm 750 \mathrm{mV}$ tarama aralığında $1 \mathrm{mV} / \mathrm{sn}$ tarama hızıyla uygulanan bir döngüsel polarizasyon ölçümü gerçekleştirilmiştir. Her grup için yeni solüsyon kullanılmıştır. Doğrudan cihazdan okunan eğrilerden korozyon potansiyeli (Ekor), korozyon akım yoğunluğu (Ikor) ve korozyon hızı Tafel ekstrapolasyon yöntemi ile hesaplanmıştır.

\section{Sonuçlar ve Tartışma}

Farklı miktarlarda Mo ilave edilen 17-4 PH paslanmaz çeliklerin mikro yapı SEM görüntüleri Şekil 1'de verilmiştir.
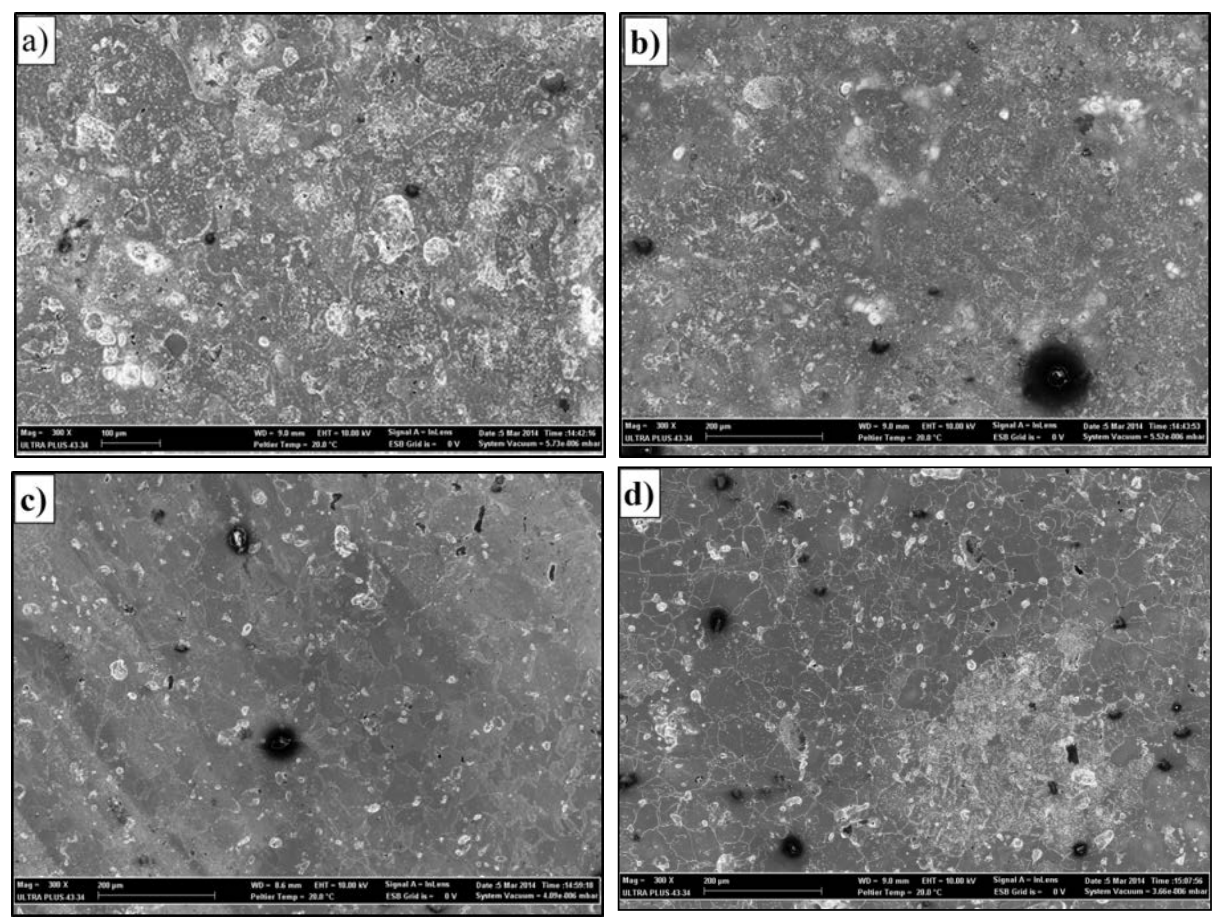

Şekil 1. Farklı miktarlarda Mo ilave edilen 17-4 PH paslanmaz çeliklerin mikro yapı SEM görüntüleri a) $\% 0,5 \mathrm{Mo}$, b) $\% 1$ Mo, c) $\% 2 \mathrm{Mo}$ ve d) $\% 4$ Mo.

Şekil 1'de farklı miktarlarda Mo ilave edilen 17-4 PH paslanmaz çelik alaşımların mikro yapı SEM görüntüleri incelendiğinde, alaşımların yapısında Fe açısından zengin ( $\delta$-ferrit) bölgelerle birlikte mikro boşlukların (siyah bölgeler) da olduğu görülmektedir. Daha önce yapılan çalışmalarda da benzer sonuçlar belirtilmiştir [9 ve 10]. Ayrıca alaşımın yapısında nokta şeklindeki beyaz bölgelerin $\mathrm{Cr}$ (krom) ve $\mathrm{C}$ (karbon)- zengin bölgeler olduğu düşünülmektedir. Nalçacıŏglu [2], yaptığı bir çalışmada bu bölgelerin $\mathrm{Cr}$ ve C-zengin bölgeler olduğunu ve bu bölgelerde karbür oluşumunun bir göstergesi olduğunu belirtmiştir. Ayrıca Şekil 2'de verilen XRD analiz sonucu bu durumu desteklemektedir. Ayrıca yapıda oluşan gözenekler (mikro boşluklar), toz metalürjisi yönteminin kaçınılmaz bir 
sonucudur. Dolayısıyla oluşan gözenekler üretilen alaşımın yoğunluğunu etkileyen önemli bir parametredir [11]. Farklı miktarlarda Mo ilave edilen 17-4 PH paslanmaz çeliklerin XRD sonuçları Şekil 2'de verilmiştir.

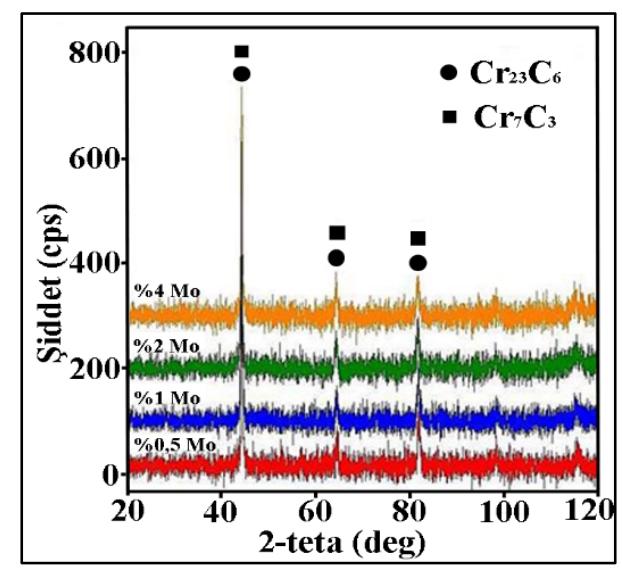

Şekil 2. Farklı miktarlarda Mo ilave edilen 17-4 PH paslanmaz çeliklerin XRD sonuçları.

Şekil 2'de verilen farklı miktarlarda Mo ilave edilen 17-4 PH paslanmaz çeliklerin XRD analiz sonucu incelendiğinde, beklendiği gibi yapıda karbürlerin oluştuğu görülmektedir. Yapıda oluşan karbürlerin $\mathrm{Cr}_{23} \mathrm{C}_{6}$ ve $\mathrm{C}_{7} \mathrm{C}_{3}$ şeklinde oluştuğu görülmektedir. Yapıda oluşan bu karbürler malzemenin mekanik özelliklerini artıran önemli fazlardır [12 ve 13]. Farklı miktarlarda Mo ilave edilen 17-4 PH paslanmaz çeliklerin yoğunluk ve sertlik değişimleri Şekil 3’te verilmiştir.

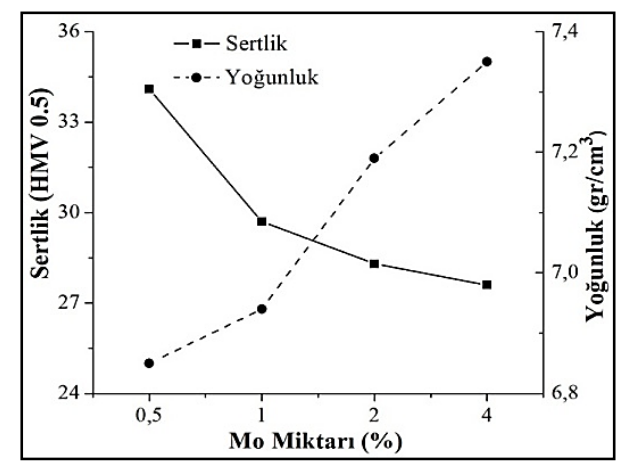

Şekil 3. Farklı miktarlarda Mo ilave edilen 17-4 PH paslanmaz çeliklerin sertlik ve yoğunluk değişimleri.

Şekil 3'te verilen farklı miktarlarda Mo ilave edilen 17-4 PH paslanmaz çeliklerin yoğunluk sonuçları incelendiğinde, 17-4 PH paslanmaz çeliklerin bileşimindeki Mo miktarına bağlı olarak, alaşımların yoğunluklarının arttığı açıkça görülmektedir. Yapılan bazı çalışmalarda yoğunluk artışının sinterleme süresi ve sinterleme sıcaklığı gibi iki önemli parametrenin olduğu belirtilmektedir [14 ve 15]. Bu parametrelerin yanı sıra sıvı faz sinterlemesi ise diğer önemli bir parametredir [16]. Yoğunluktaki bu artışın bu parametreler ile açıklanması bu çalışma kapsamında mümkün değildir. Yoğunluktaki bu artışın nedeni alaşım içerisinde ilave edilen Mo miktarı ile açıklanabilir. Mo yoğunluğunun 17-4 PH alaşım yoğunluğundan yüksek olması ölçülen yoğunluğun Mo miktarı ile artmasının temel nedenidir. Şekil 3’te verilen sertlik sonuçları incelendiğinde ise artan Mo miktarı ile birlikte sertliğin azaldığı açık bir şekilde görülmektedir. Yapılan bu çalışmada 17-4 PH alaşımına ilave edilen Mo element ilavesi ile sertliğin artması öngörülmüştü. Ancak ilave edilen Mo elementinin yüksek ergime sıcaklığına sahip olmasından dolayı, katı eriyik içerisinde çözünürlüğünün sınırlı olmasından kaynaklanmaktadır. Daha önce yapılan bir çalışmada benzer sonuçlar elde 
Nevşehir Bilim ve Teknoloji Dergisi (2019), 8(IMSMATEC Özel Sayı) 98-104

edilmiştir [2]. Farklı miktarlarda Mo ilave edilen 17-4 PH paslanmaz çeliklere ait polarizasyon eğrileri Şekil 4'te, akımpotansiyel ölçümlerinden elde edilen korozyon parametreleri ise, Tablo 2'de verilmiştir.

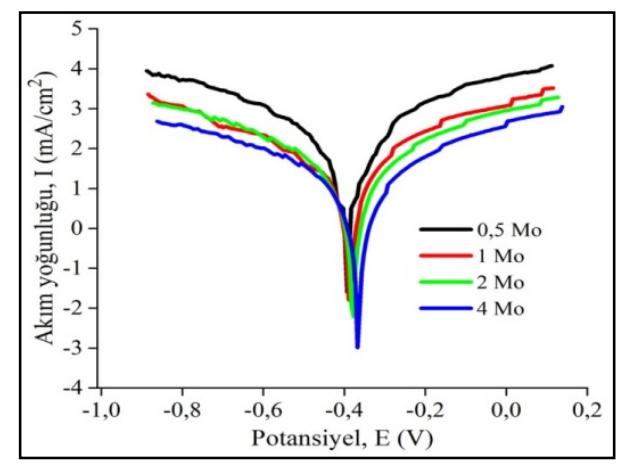

Şekil 4. Farklı miktarlarda Mo ilave edilen 17-4 PH paslanmaz çeliklerin polarizasyon tafel eğrileri.

Tablo 2. Farklı miktarlarda Mo ilave edilen 17-4 PH paslanmaz çeliklerin korozyon parametreleri.

\begin{tabular}{cccccc}
\hline Elektrot & $\begin{array}{c}\mathrm{E}_{\mathrm{kor}} \\
(\mathrm{mV})\end{array}$ & $\begin{array}{c}\mathrm{I}_{\mathrm{kor}} \\
\left(\mathrm{mA} / \mathrm{cm}^{2}\right)\end{array}$ & $\begin{array}{c}\beta \mathrm{a} \\
(\mathrm{mV})\end{array}$ & $\begin{array}{c}\beta \mathrm{c} \\
(\mathrm{mV})\end{array}$ & $\begin{array}{c}\text { Korozyon oranı } \\
(\mathrm{mm} / \mathrm{y} 1)\end{array}$ \\
\hline $\mathbf{0 , 5}$ Mo & $-391,3$ & 708,3 & 220 & 45 & 0,807 \\
$\mathbf{1 ~ M o}$ & $-384,1$ & 556,4 & 12,46 & 106,1 & 0,665 \\
$\mathbf{2 ~ M o}$ & $-375,5$ & 221,3 & 69,43 & 78,68 & 0,585 \\
4 Mo & $-365,5$ & 216,6 & 220 & 450 & 0,344 \\
\hline
\end{tabular}

Şekil 4'te verilen potansiyel akım grafiği incelendiğinde, farklı miktarlarda Mo ilave edilen 17-4 PH paslanmaz çeliklerin korozyon potansiyel eğrilerinin birbirine benzediği görülmektedir. Fakat bu eğrilerden elde edilen veriler (Tablo 2) incelendiğinde, numuneler arasında en yüksek korozyon oranı 0,5 Mo ilave edilen numunede, en düşük korozyon oranı ise 4 Mo ilave edilen numunede görülmektedir. 0,5 Mo ilave edilen numunenin Ikor değeri, 708,3 $\mathrm{mA} / \mathrm{cm}^{2}$ ve korozyon oran $10,807 \mathrm{~mm} / \mathrm{y} 1 \mathrm{l}, 4$ Mo ilave edilen numunenin Ikor değeri, $216,6 \mathrm{~mA} / \mathrm{cm}^{2}$ ve korozyon oranı $0,344 \mathrm{~mm} / \mathrm{y} 1 \mathrm{l}$ olarak ölçülmüştür. Yani, 4 Mo ilave edilen numunenin korozyon direnci, diğer numunelere oranla yüksektir. Artan molibden miktarı ile korozyon direncinin arttığı anlaşılmaktadır. Karaminezhaad vd. [8] yaptığı bir çalışmada yaşlandırma yapılan 17-4 PH paslanmaz çeliklere farklı miktarlarda molibden ilave etmişlerdir. Sonuç olarak artan Mo miktarı ile korozyon direncinin artmasının alaşım içerisinde artan Mo miktarı ile yapıda ( $\delta$-ferrit) alanlarının genişlemesinden dolayı olduğunu, mukavemetin azaldığını ve korozyon direncinin arttığını belirtmişlerdir. Yine yapılan başka bir çalışmada östenitik paslanmaz çeliklere ilave edilen molibdenin korozyon direncini olumlu yönde geliştirdiği belirtilmiştir [17].

\section{Sonuçlar}

Farklı miktarlarda Mo ilave edilerek üretilen 17-4 PH paslanmaz çelik alaşımlarına farklı miktarlarda Mo ilavesinin korozyon davranışlarına etkisinin araştırıldığı bu çalışmada elde edilen sonuçlar aşağıda belirtilmiştir.

- Üretilen alaşımlarda yapının genel olarak, demirce zengin ( $\delta$-ferrit) bölgelerin oluştuğu ve yapıda gözeneklerin oluştuğu görülmüş̧ür.

- XRD sonuçlarında yapıda $\mathrm{Cr}_{23} \mathrm{C}_{6}$ ve $\mathrm{Cr}_{7} \mathrm{C}_{3}$ karbürlerin oluştuğu belirlenmiştir.

- Üretilen alaşımların yoğunluklarının, alaşımın içerisine ilave edilen Mo miktarı ile arttığı en yüksek yoğunluğun \%4 Mo ilave edilen alaşımda olduğu belirlenmiştir.

- Üretilen alaşımların sertlik sonuçlarında, alaşım içerisinde artan Mo miktarına bağlı olarak alaşımın sertliğinin azaldığ 1 en yüksek sertlik değerinin \% 0,5 Mo ilave edilen alaşımda olduğu belirlenmiştir. 
Nevşehir Bilim ve Teknoloji Dergisi (2019), 8(IMSMATEC Özel Sayı) 98-104

- Alaşım içerisinde artan Mo miktarı ile korozyon direncinin arttığı, en yüksek korozyon direncinin \% 4 Mo ilave edilen alaşımda olduğu görülmüştür.

5. Kaynaklar

[1] Ping, L. I., Cai, Q. Z., Wei, B. K., Zhang, X. Z., "Effect of aging temperature on erosion-corrosion behavior of 17-4 PH stainless steels in dilute sulphuric acid slurry” Journal of Iron and Steel Research, International, 13(5), 73-78, 2006.

[2] Nalcacioglu, E., Ozyurek, D., Cetinkaya, K., "Investigation of the effect of molybdenum amount on wear behaviour of 17-4 PH stainless steel produced by powder metallurgy” Journal Of The Balkan Tribological Association, 22(1), 261-271, 2016.

[3] Wang, J., Zou, H., Li, C., Qiu, S., Shen, B., “The spinodal decomposition in 17-4PH stainless steel subjected to long-term aging at $350^{\circ} \mathrm{C}^{\prime \prime}$ Materials Characterization, 59(5), 587-591, 2008.

[4] Tavares, S.S.M., Da Silva, F.J., Scandian, C., Da Silva, G.F., De Abreu, H.F.G., "Microstructure and intergranular corrosion resistance of UNS S17400 (17-4 PH) stainless steel” Corrosion Science, 52(11), 38353839, 2010.

[5] Bühler, H. E., Gerlach, L., Greven, O., Bleck, W., "The electrochemical reactivation test (ERT) to detect the susceptibility to intergranular corrosion” Corrosion Science, 45(10), 2325-2336, 2003.

[6] Greene, N. D., Fontana, M.G., “A critical analysis of pitting corrosion” Corrosion, 15(1), 41-47, 1959.

[7] Truman, J. E., Coleman, M. J., Pirt, K. R., "Note on the influence of nitrogen content on the resistance to pitting corrosion of stainless steels” British Corrosion Journal, 12(4), 236-238, 1977.

[8] Karaminezhaad, M., Sharafi, S., Dalili, K., "Effect of molybdenum on SCC of 17-4PH stainless steel under different aging conditions in chloride solutions” Journal of Materials Science, 41(11), 3329-3333, 2006.

[9] Gülsoy, H.Ö., Salman, S., Özbek, S., "Effect of FeB additions on sintering characteristics of injection moulded 17-4 PH stainless steel powder” Journal of Materials Science, 39(15), 4835-4840, 2004.

[10] Gülsoy, H.Ö., "Influence of nickel boride additions on sintering behaviors of injection moulded 17-4 PH stainless steel powder” Scripta Materialia, 52(3), 187-192, 2005.

[11] German, R.M. (1996), “Sintering theory and practice” Solar-Terrestrial Physics, Wiley-VCH, 568.

[12] Çetinkaya, C., "An investigation of the wear behaviours of white cast irons under different compositions" Materials \& Design, 27(6), 437-445, 2006.

[13] Kalyon, A., Özyürek, D., Günay, M., Aztekin, H., "Dry sliding wear behaviours of valve seat inserts produced from high chromium white iron” High Temperature Materials and Processes, 34(7), 635-641, 2015.

[14] Wu, Y., German, R.M., Blaine, D., Marx, B., Schlaefer, C., "Effects of residual carbon content on sintering shrinkage, microstructure and mechanical properties of injection molded 17-4 PH stainless steel” Journal of Materials Science, 37(17), 3573-3583, 2002.

[15] Wu, Y., Blaine, D., Schlaefer, C., Marx, B., German, R.M., "Sintering densification and microstructural evolution of injection molding grade 17-4 PH stainless steel powder” Metallurgical and Materials Transactions A, 33(7), 2185-2194, 2002.

[16] Salahinejad, E., Hadianfard, M.J., Ghaffari, M., Mashhadi, S.B., Okyay, A.K., "Liquid-phase sintering of medical-grade P558 stainless steel using a new biocompatible eutectic additive” Materials Letters, 74, 209212, 2012. 
Nevşehir Bilim ve Teknoloji Dergisi (2019), 8(IMSMATEC Özel Sayı) 98-104

[17] Szewczyk-Nykiel, A., “The influence of molibdenum on corrosion resistance of sintered austenitic stainless steels” Czasopismo Techniczne, (Mechanika Zeszyt 4-M (26) 2015), 131-142, 2016.

\section{Extended Abstract}

\section{Introduction}

17-4 PH stainless steels containing 17\% Cr, 4\% Ni, 3\% Cu as alloying elements (by weight) are widely used because of their good corrosion resistance and low cost. Another characteristic of these alloys is their hardness by precipitation. Hardenability is one of the materials developed to achieve high strength and hardness values while maintaining the corrosion resistance of stainless steels. These alloys are used as part of pumps and valves in chemical industry, power plants, and light water reactors, pressurized water reactors due to their high strength, fracture toughness, good weldability and machinability. Mechanical properties of 17-4 PH alloys can be improved by aging processes, while corrosion properties are adversely affected. This is one of the major problems of stainless steels. In the treatment by aging, the formation of chromium carbides occurs by diffusion and generally condenses at the grain boundaries. This results in chromium depletion in a narrow region. In an electrolyte, these regions become anodic. In general, the result of the precipitation of carbides significantly affects the corrosion resistance. In addition, the addition of alloying elements in 17-4 PH stainless steels significantly affects the mechanical properties as well as the corrosion properties. The addition of Mo (Molybdenum) added to stainless steels increases the pitting corrosion resistance. In this study, stainless steel alloy was produced by adding different amounts of Mo to 17-4 PH alloy by powder metallurgy method. It is aimed to determine the effect of molybdenum added on the microstructure, hardness and corrosion behaviors of different amounts of 17-4 PH stainless steels.

\section{Method}

In the production of 17-4 PH stainless steels $\mathrm{Cu}, \mathrm{Fe}, \mathrm{Cr}, \mathrm{Mn}, \mathrm{Ni}, \mathrm{C}, \mathrm{Mo}, \mathrm{Si}, \mathrm{Nb}$ elemental powders were used. The supplied elemental powders were weighed on a balance of 1/10000 and mixed at 120 rpm for 120 minutes in a Turbula Shaker Mixer. The prepared alloy powders are cold pressed $(800 \mathrm{MPa})$ to produce $\varnothing 10 \mathrm{x} 7 \mathrm{~mm}$ raw compacts. The preformed 17-4 PH stainless steel crude compacts were sintered at $1300^{\circ} \mathrm{C}$ for 60 minutes $\left(10^{-6}\right.$ millibars in vacuum and at a heating rate of $4^{\circ} \mathrm{C} / \mathrm{min}$ ) and cooled in the oven to room temperature. Density measurements were made according to the Archimedes' principle. Hardness measurements were made by Shimadzu brand micro hardness tester (HV0.5). After the surfaces of the sintered and aged samples were prepared by standard metallographic processes, all samples were etched by electrolytic etching (12 V) in a solution containing 25\% oxalic acid, $75 \%$ pure water. Etched samples (SEM + EDS) brand scanning electron microscope and X-ray diffraction (XRD) were examined. Corrosion tests were performed on Iviumstat computer controlled potentiostat / galvanostat tester. Potentiodynamic polarization technique was used in corrosion tests. $0.1 \mathrm{M} \mathrm{H}_{2} \mathrm{SO}_{4}$ solution was used as the electrolyte medium. Tests a cyclic polarization measurement was performed with a scanning rate of $1 \mathrm{mV} / \mathrm{sec}$ in the scanning range of $\pm 750 \mathrm{mV}$.

\section{Results and Discussion}

When the microstructures of 17-4 PH stainless steel alloys were added with different amounts of Mo, it was observed that iron rich ( $\delta$-ferrite) regions were formed and pores formed in the structure. XRD results showed that $\mathrm{Cr}_{23} \mathrm{C}_{6}$ and $\mathrm{Cr}_{7} \mathrm{C}_{3}$ carbides were formed in the structure. When the density results of 17-4 PH stainless steels with different amounts of Mo added were examined, it was clearly seen that the densities of the alloys increased depending on the amount of Mo in the composition of the alloys. The reason for this increase in density can be explained by the amount of Mo added in the alloy. Mo density higher than 17-4 PH alloy density is the main reason why the measured density increases with the amount of Mo. When the hardness results were examined, it was clearly seen that hardness decreased with increasing Mo amount. The decrease in hardness is due to the limited solubility in the solid solution, since the added Mo element has a high melting temperature. When corrosion results were examined, the highest corrosion rate was observed in the sample with 0.5 Mo added and the lowest corrosion rate was observed in the sample with 4 Mo added in 17-4 PH stainless steels with different amounts of Mo added. The $\mathrm{I}_{\text {corr }}$ value of the sample with 0.5 Mo added was 708.3 $\mathrm{mA} / \mathrm{cm}^{2}$ and the corrosion rate was $0.807 \mathrm{~mm} /$ year, the $\mathrm{I}_{\text {corr }}$ value of the sample with 4 Mo added was $216.6 \mathrm{~mA} / \mathrm{cm}^{2}$ and the corrosion rate was $0.344 \mathrm{~mm} /$ year. That is, the corrosion resistance of the sample with 4 Mo added is higher compared to other samples. Increased amount of molybdenum is understood to increase corrosion resistance. 